\title{
USING THERMAL CONCENTRATOR FOR PERFORMANCE DEVELOPMENT OF SOLAR BOX COOKER
}

\author{
Abdel-Salam, M. F. ${ }^{1}$ and M. F. Atia ${ }^{2}$
}

\begin{abstract}
The study aims to construct, develop and evaluate the performance of solar box cooker viz non-modified and modified. A box-type solar cooker was constructed, and the cooker was supplied with a solar concentrator with dual tracking system to improve the gained heat. The tests have been carried out in Shubra El-Kheima, Egypt (Latitude $30^{\circ} 11^{\prime} \mathrm{N}$, Longitude $31^{\circ} 24^{\prime}$ E). The solar cookers were not loaded, and loaded with 0.5, 1.0 and 2.0 liter of water. The modified box was filled with different volumes of rice and $210 \mathrm{~g}$ of biscuit. The thermal performance was evaluated by using first figure of merit F1, second figure of merit F2 and energy efficiency. The calculated values of F1 was 0.108 and 0.087 oC.m2/W for modified and non-modified cooker, respectively. The value of F2 was 0.262 and 0.089 for modified and non-modified cooker, respectively. The modified cooker achieved a higher temperature than the non-modified cooker by about $23 \%$ at the maximum water mass of 2 l. The total required time was about 255 min for cooking a $1000 \mathrm{~g}$ of rice, and 90 min for baking a $210 \mathrm{~g}$ of biscuit. The cost of the modified cooker saves about $20.8 \%$ of the operation cost of the traditional gas cooker. The maturity of cooking of solar-cooked rice and biscuit was checked, the values of hardness for cooked rice and baked biscuit was agreed with the references values.
\end{abstract}

Keywords: Solar thermal applications, Solar cooker, solar Box cooker, Solar thermal concentrators, Performance of solar thermal systems.

\section{INTRODUCTION}

olar thermal energy offers an alternative solution for energy supply problems that are concerned with cooking especially in rural and remote locations, Harmim et al. (2012).

\footnotetext{
${ }^{1}$ Assist. Prof. of Agric. Eng. Dept., Fac. of Agric., Ain Shams University.

${ }^{2}$ Lecturer of Agric. Eng. Dept., Fac. of Agric., Ain Shams University.
} 
The solar cooking is a green method for cooking in addition to reduce money and efforts of bringing the conventional fuels from urban areas El-Shal (2016). Solar cookers fall within three main categories called; solar panel cookers, solar parabolic cookers and solar box cookers. Egypt has a high potential to produce solar energy that can be considered as a reliable energy source, the average solar energy has a magnitude of 5 to 8 $\mathrm{kWh} / \mathrm{m}^{2}$ per day and sunshine period per year extends to about 3500 hours Sorensen, (2003).

Although the box-type solar cookers performances are not high, and their cooking time may vary from 2 to $3 \mathrm{~h}$, they are most popular and widely used in many countries due to their simplicity and low cost Merzouk et al., (2012). To improve the performances of box-type solar cooker many works were carried out by several researchers. Some researchers brought solutions to enhance the heat capacity of box-type solar cookers by increasing the solar irradiation in the box with the help of reflectors. These various works have led to more effective box-type solar cookers but always requiring movements and reflector adjustments for collecting solar radiation throughout the year or the season Amer (2003), Mirdha and Dhariwal (2008). Dang (1986) investigated the concentrators for flat plate collectors to provide extra solar radiation in order to increase the efficiency of solar collectors, the results indicated that the effectiveness of concentrators highly depends on the angle of mirrors.

Negi and Purohit (2005) compared the performances of a conventional box type cooker and a concentrator cooker, the experimental results showed that the concentrator cooker provided stagnation temperature 15$22{ }^{\circ} \mathrm{C}$ higher than the conventional box cooker, also the boiling point of water with concentrator cooker is reached faster by 50-55 $\mathrm{min}$, than the conventional box cooker. Arenas (2007) described a portable solar kitchen with parabolic solar reflector that folded up into a small volume, the experimental study indicated that the solar cooker reached an average power output of $175 \mathrm{~W}$, with an energy efficiency of 26.6\%. Ozturk (2007) compared energy efficiencies of box-type and parabolic-type solar cookers, experimental study indicated that the power output of the boxtype cooker ranged from 8.2 to $60.2 \mathrm{~W}$, whereas it varied between 20.9 
and 73.5 W for the parabolic cooker. Atia et al. (2016) stated that the tracking device was able to track the motion of sun and keep the solar concentrator in a straight axis to the sun, and the tracking device was led to increase of the cumulative daily heat gain by approximately $59 \%$.

So, the specific aims of this study were:

1- develop and improve solar cooker system.

2- study the factors that effect on the performance of the system.

3 - use and test the developed cooker in the cooking and baking.

4 - evaluate the system.

\section{MATERIALS AND METHODS}

A box-type solar cooker was built and was modified to improve its thermal performance. The experiments were carried out in Department of Agricultural Engineering, Faculty of Agriculture, Ain Shams University, Shubra El-Khemia, Egypt (Latitude $30^{\circ} 11^{\prime}$ N, Longitude $31^{\circ} 24^{\prime}$ E).

\section{Specification of the box type solar cooker}

Two box type solar cookers have been built to compare and evaluate the performance of them for cooking. One of them is non-modified and the other is modified.

\section{Non-modified box solar cooker}

The non-modified solar cooker as shown in Fig. (1), it consists of; wooden box, absorber plate, and cooking pot

The dimensions of the wooden box is $60 \mathrm{~cm}$ in length, $50 \mathrm{~cm}$ in width, and $50 \mathrm{~cm}$ in height. It was painted with a matt black. The front side was inclined at $45^{\circ}$ according to Harmim et al. (2010) The internal sides are covered by polished stainless steel $0.4 \mathrm{~mm}$ of thickness to reflect sunrays on the absorber plate. The inclined side was provided with double-glass cover $4 \mathrm{~mm}$ separated with $2 \mathrm{~cm}$ according to Duffle and Backman (2006) and Saxena et al. (2011). The outsides and the bottom of the absorber plate is insulated by $5 \mathrm{~cm}$ glass-wool.

The absorber plate was made from plane aluminum sheet painted with a matt black, it has $60 \mathrm{~cm}$ in length, $50 \mathrm{~cm}$ in width, and $0.8 \mathrm{~mm}$ in thickness.

The cooking pot was made of aluminum painted matt black, cylindrical in shape and had flat base. It had a diameter of $21 \mathrm{~cm}$, a height of 11.5 
$\mathrm{cm}$ and thickness of $0.27 \mathrm{~cm}$. It was placed in the center of the absorber plate inside the cooker box.

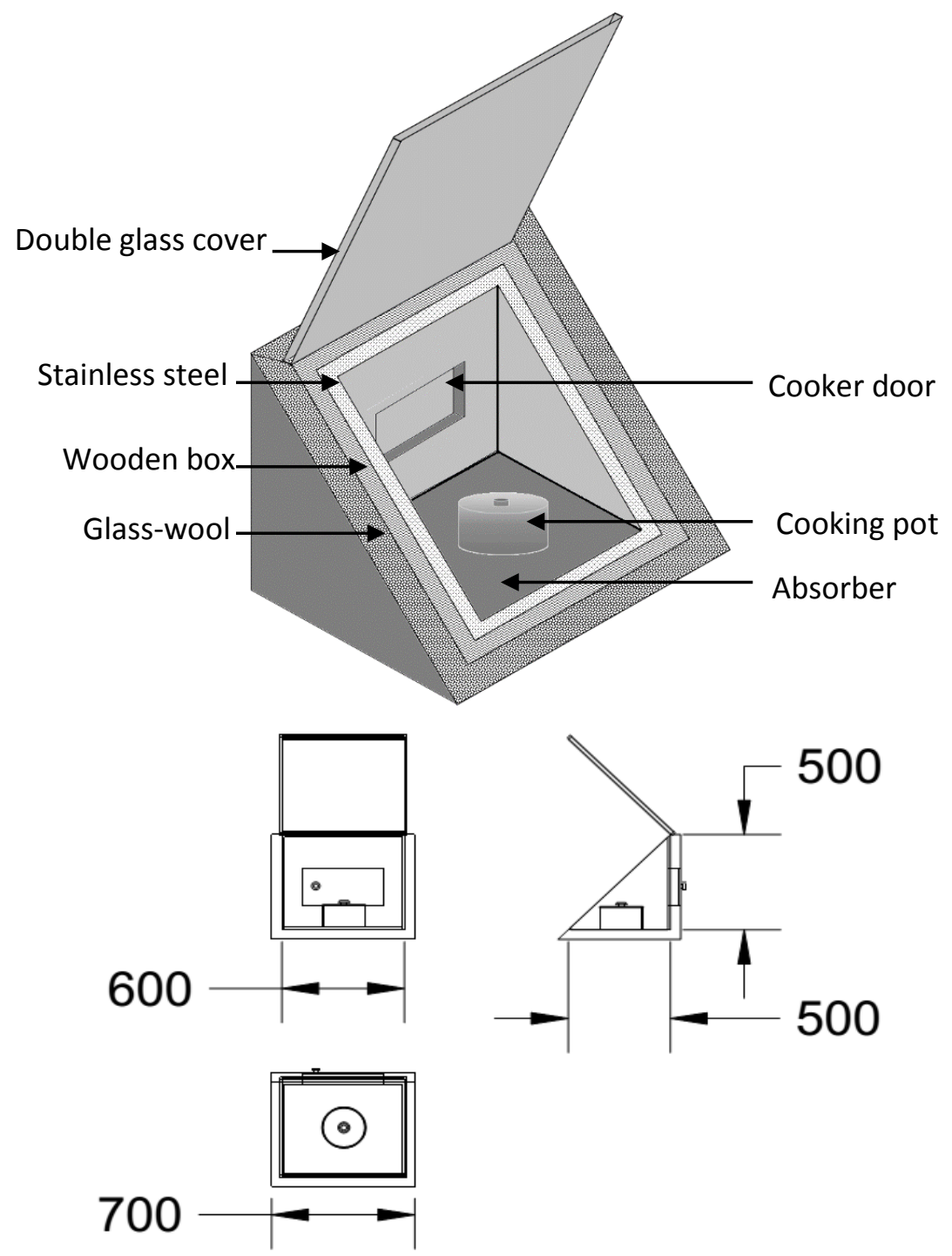

Fig. (1): Non-modified box solar cooker, the dimensions in $\mathbf{m m}$.

\section{Modified box solar cooker}

The modified box solar cooker, is similar to the non-modified box solar cooker in construction and the cooker was supplied with a solar concentrator with tracking system to improve the gained heat. The solar concentrator with tracking system has been designed by Atia et al., (2016). 


\section{A solar parabolic dish collector}

A solar parabolic dish collector, has aperture diameter equal to $1.44 \mathrm{~m}$ with focal length of $0.69 \mathrm{~m}$. Its interior surface was covered with polished stainless to reflect and concentrate sunrays to a point focus. The parabolic dish was equipped with dual-axis electromechanical tracking system.

\section{Heat absorber plate}

The heat absorber plate was placed in focal point of the parabolic dish faced the polished stainless to absorb the reflected sunrays. It was made of aluminum painted matt black with a square shape of $0.09 \mathrm{~m}^{2}$. It was contacted with a copper tube painted matt black which was formed to serpentine shape with $16 \mathrm{~mm}$ in outer diameter, $0.1 \mathrm{~mm}$ in thickness, and $2.37 \mathrm{~m}$ in length. It was put in aluminum box and insulated by $25 \mathrm{~mm}$ glass wool around its sides.

\section{The whole modified system}

As shown in Fig. (2) in the cooker box, the bottom of the absorber plate was contacted with a copper tube painted matt black which was formed to serpentine shape with $10 \mathrm{~mm}$ in outer diameter, $0.1 \mathrm{~mm}$ in thickness, and $2 \mathrm{~m}$ in length. The input and output of the tube were fitted with the output and input at respectively of the fluid tube from the solar concentrator to form a closed-loop of working fluid (oil).

Heat absorber plate

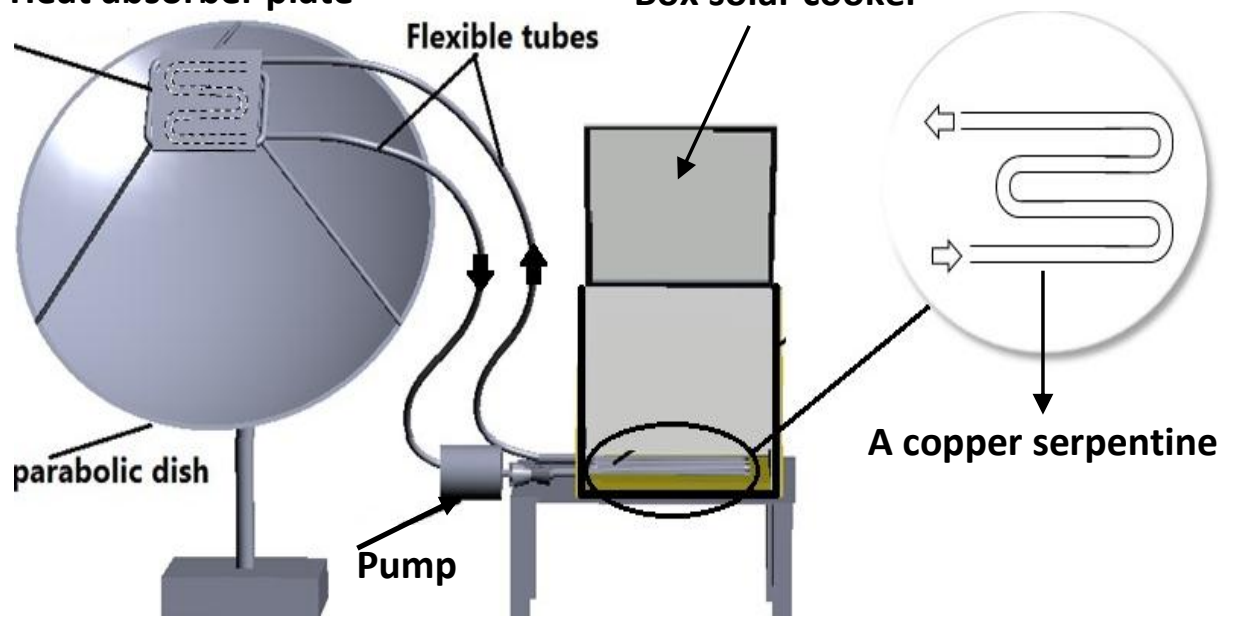

Fig. (2): Modified solar box cooker. 


\section{Experiments and Measurements}

As shown in Fig. (3), two experimental set-up were carried out of each prototype; one of them was non-modified and the other was a modified solar cooker.

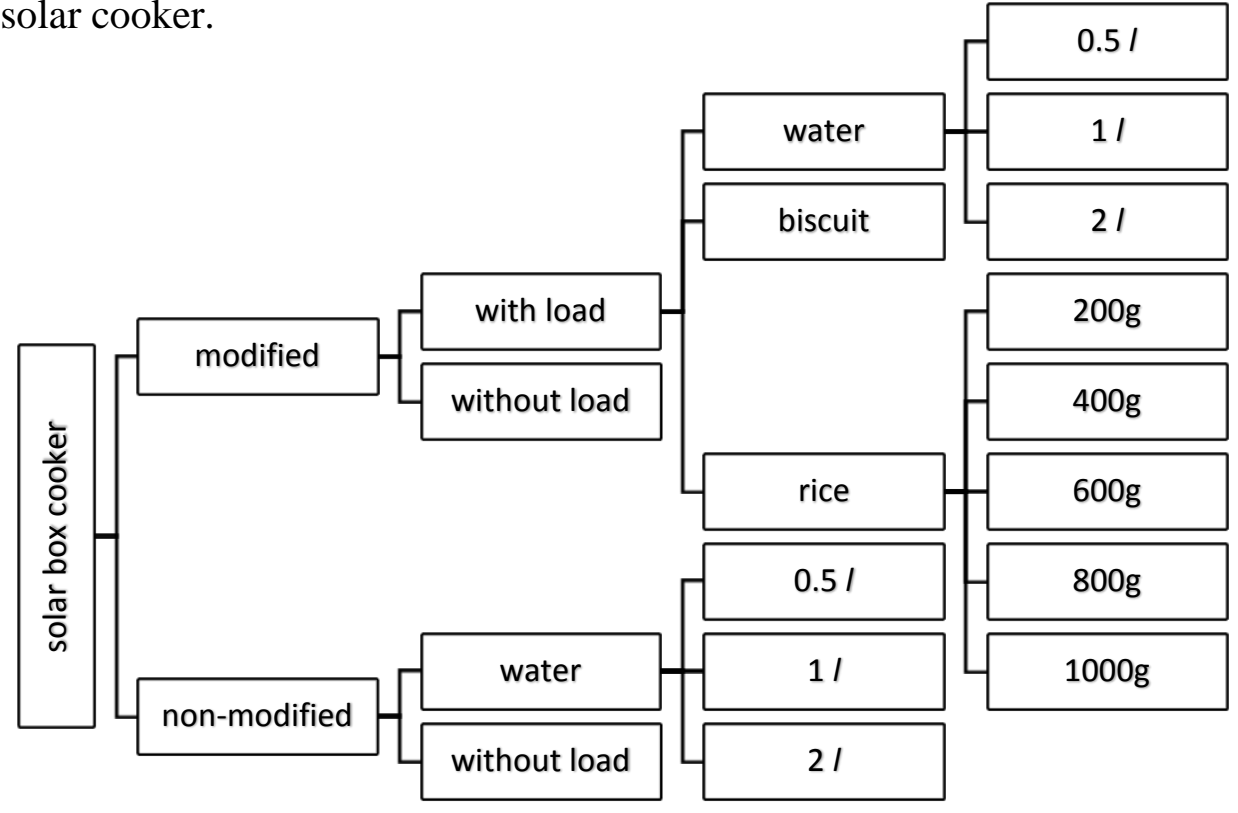

Fig. (3): Flow chart of experiments was carried out on the cookers.

In the non-modified solar cooker, Sun rays hitting the inner sidewalls. The reflected sidewalls reflect and concentrate the sun rays on the absorber in the bottom.

In the modified solar cooker, there are two sources of the gain heat. One of them is similar to the non-modified solar cooker and the other one is from the parabolic dish.

In the modified prototype, the closed loop was filled with soya bean oil. The sun rays falling on the reflective surface of the solar dish. The reflective surface reflects and concentrates the sun rays on the heat absorber plate that is in the focal point of the parabolic dish. The heat absorber transforms the concentrated sunrays into heat energy. The oil is heated up and flows out to the copper serpentine inside the cooker under the cooking pot then returned to the heat absorber again by centrifugal pump to more heating up and so on. The oil was circulated in the closed loop through insulated flexible tubes. 
A series of tests were performed with one cooking pot filled with different quantity of water; $0.5,1.0$ and 2.0 liter to evaluate the thermal performance of the system.

For test the cooking, cooking pot of the solar cookers was filled with different volumes of rice with; 200, 400, 600, 800 and1000 g. Every quantity of rice to needs 1.5 times of water to cook Deliani (2004). The rice needs a temperature of $78{ }^{\circ} \mathrm{C}$ to complete the cooking process for a specific period of time which varies according to the quantity of rice, Yusufzai, (1994).

For test the baking, samples of biscuit dough were placed on the plate of the cooker with thickness 3-4 $\mathrm{mm}$ and diameter $40-50 \mathrm{~mm}$, Biscuit dough was tested for baking in the modified box and modified truncated pyramid solar cookers by $210 \mathrm{~g}$ and $110 \mathrm{~g}$ in weight, respectively. The ingredients of biscuit were fat, flour, sucrose, salt, and baking powder according to Burseg et al. (2009).

Measurements are monitored at an interval of 10 min during the period range from 9.00 am to $4.00 \mathrm{pm}$ on summer season 2017. The measured parameters were as follows; Ambient air temperature $\left(\mathbf{T}_{\mathbf{a m b}}\right)$, Absorber plate temperature of the cooker box $\left(\mathbf{T}_{\mathbf{a b}}\right)$, Water temperature in the cooking pot $\left(\mathbf{T}_{\mathbf{w a t}}\right)$, Temperature of oil at inlet of the solar absorber $\left(\mathbf{T}_{\mathbf{o .}}\right)$, Temperature of oil at outlet of the solar absorber $\left(\mathbf{T}_{\mathbf{0 . 0}}\right)$, Air temperature inside the cooker box $\left(\mathbf{T}_{\mathbf{i}}\right)$ and Solar radiation $\left(\mathbf{I}_{\mathbf{s}}\right)$

The temperatures are measured by thermocouples (type K) which were coupled to digital thermometer. Also, the solar radiation was measured by pyranometer with sensitivity $14.11 * 10^{-6} \mathrm{v} / \mathrm{W} . \mathrm{m}^{-2}$.

\section{System evaluation Methodology}

\section{First figure of merit F1}

This test was carried out under no-load and clear sky condition. The first figure of merit $(\mathbf{F 1})$ presents the ratio of optical efficiency $(\boldsymbol{\eta})$ to the heat loss factor $\left(\boldsymbol{U}_{\boldsymbol{L} S}\right)$ and mathematically expressed by Kumar, (2005):

$$
F 1=\frac{\eta}{U_{L S}}=\frac{T_{a b}-T_{a m b}}{I_{S}}
$$

Where; F1: the first figure of merit $\left({ }^{\circ} \mathrm{C} . \mathrm{m}^{2} / \mathrm{W}\right), \boldsymbol{\eta}$ : the optical efficiency $(\%), \mathbf{U}_{\mathbf{L S}}$ : the heat loss factor $\left(\mathrm{W} /{ }^{\circ} \mathrm{C} \cdot \mathrm{m}^{2}\right), \mathbf{T}_{\mathbf{a b}}$ : the absorber plate 
temperature $\left({ }^{\circ} \mathrm{C}\right), \mathbf{T}_{\mathbf{a m b}}$ : the ambient temperature $\left({ }^{\circ} \mathrm{C}\right)$ and $\mathbf{I}_{\mathbf{s}}$ : the solar radiation $\left(\mathrm{W} / \mathrm{m}^{2}\right)$.

The higher values of F1 would indicate better cooker performance, good optical efficiency, and low heat loss factor.

\section{Determination of F2 (Second figure of merit F2)}

The $\mathbf{F}_{\mathbf{2}}$ is obtained by heating the containers (full of water) placed on the absorber plate, it's mathematically expressed by Kumar, (2005):

$$
F_{2}=\frac{F_{1}(M . C)_{w}}{A\left(t_{2}-t_{1}\right)} \ln \left[\frac{1-\left(T_{w 1}-T_{a m b}\right) / F_{1} I}{1-\left(T_{w 2}-T_{a m b}\right) / F_{1} I}\right]
$$

Where: $\mathbf{t}_{\mathbf{1}}$ : the time when water temperature reached $\mathbf{T}_{\mathbf{W} \mathbf{1}}\left({ }^{\circ} \mathbf{C}\right), \mathbf{t}_{\mathbf{2}}$ : the time when water temperature reached $\mathbf{T}_{\mathbf{W}_{2}}\left({ }^{\circ} \mathrm{C}\right),\left(\mathbf{t}_{\mathbf{2}}-\mathbf{t}_{\mathbf{1}}\right)$ : the time taken for heating water from $\mathbf{T}_{\mathbf{W} \mathbf{1}}$ to $\mathbf{T}_{\mathbf{W} \mathbf{2}}(\mathrm{sec}), \mathbf{T}_{\mathbf{a m b}}$ : the average ambient temperature from the time period $\mathbf{t}_{\mathbf{1}}$ to $\mathbf{t}_{\mathbf{2}}\left({ }^{\circ} \mathrm{C}\right)$, $\mathbf{I}$ : the average solar radiation from the time period $\mathbf{t}_{\mathbf{1}}$ to $\mathbf{t}_{\mathbf{2}}\left(\mathrm{W} / \mathrm{m}^{2}\right)$ and $(\mathbf{M} . \mathbf{C})_{\mathbf{w}}$ : mass of product of water and specific heat $\left(\mathrm{J} /{ }^{\circ} \mathrm{C}\right)$.

A high value of F2 indicates the effectiveness of the heat transfer from the absorber plate and the inside air to contents of the cooking pots.

\section{Thermal performance of the system}

Thermal performance of the system depends upon the input total incident energy and heat utilized for cooking. Following equations is used for data reduction.

Total input incident energy to absorber can be determined by Ashok and Sudhir, (2009).

$$
Q_{\text {incident }}=I_{s} \times A_{S C}
$$

And energy output, i.e. energy utilized for the cooking is given by Sonage and Gavali, (2015),

$$
Q_{\text {system }}=\frac{M_{w} \times C_{w} \times\left(T_{w 2}-T_{w 1}\right)}{\Delta t}
$$

The energy efficiency of the solar cooker with inclined aperture area can be defined as the ratio of the energy gained by the solar cooker (energy utilized for the cooking) to incident energy Sonage and Gavali, (2015). Energy efficiency of the solar cooker was calculated by using the equation below:

$$
\eta_{\text {energy }}=\frac{Q_{\text {system }}}{Q_{\text {incident }}}=\frac{\frac{M_{w} \times C_{w} \times\left(T_{w 2}-T_{w 1}\right)}{\Delta t}}{I_{S} \times A_{S C}}
$$


Where: $\mathbf{M}_{\mathbf{w}}, \mathbf{C}_{\mathbf{w}}$ are the mass $(\mathrm{kg})$ and specific heat $\left(\mathrm{J} / \mathrm{kg} .{ }^{\circ} \mathrm{C}\right)$ of water, respectively. $\left(\mathbf{T}_{\mathbf{w} 2}-\mathbf{T}_{\mathbf{w 1}}\right)$ is the temperature difference between the maximum temperature and the initial temperature of water $\left({ }^{\circ} \mathrm{C}\right)$ during the interval $\Delta \mathbf{t}(\mathrm{s}), \mathbf{I}_{\mathrm{s}}$ is the solar radiation $\left(\mathrm{W} / \mathrm{m}^{2}\right)$ and $\mathbf{A}_{\mathrm{sc}}$ is the aperture area of the cooker $\left(\mathrm{m}^{2}\right)$.

\section{Maturity of cooking}

Maturity of cooking for cooked rice and biscuit was examined by a uniaxial single compression method using Tinius Olsen bench top materials testing machines model H5ks, USA. The hardness was measured as the peak force of the texture profile curve and corresponded to the force required to deform or crush the rice and biscuit. The maximum force and the distance to break off the sample were recorded and were used to refer to as the hardness of the rice and biscuit. An average value of 10 replicates was reported.

For cooked rice cylindrical probe of $25 \mathrm{~mm}$ diameter was used for compression of kernels. The test speed was $1 \mathrm{~mm} / \mathrm{s}$ according to Lee et al., (2015). While for biscuit samples a 2-mm flat-ended cylindrical probe penetrated the sample at $0.5 \mathrm{~mm} / \mathrm{s}$ according to Burseg et al., (2009).

\section{Cost estimation}

The cost price (LE/kg) of the solar cooking can be estimated by the following expression, Atia et al., (2016):

cost price

$=\frac{\text { total cost per hour }}{\text { average quantity of solar }- \text { cooked product per hour }}$

Therefore, it can be expressed mathematically as:

$$
c p=\frac{\left[\frac{c}{L \times 1500}+\frac{r \times c}{L \times 1500}\right]}{q}
$$

Where; cp: cost price of the solar-cooked rice, (LE / kg), c: establishment cost of the entire system (LE), L: life expectancy of the system, (year), (it is assumed to be 10 years), r: repairs and maintenance ratio, (it is assumed to be $3.5 \%$ of c), 1500: number of annual operation hours, and q: the average hourly quantity of cooked rice, $(\mathrm{kg} / \mathrm{h})$. 


\section{RESULTS AND DISCUSSION}

\section{Stagnation test}

The average temperature of the absorber plate inside the modified cooker was always higher than the non-modified cooker, as shows Fig. (4).

The average maximum temperature of absorber plate in the modified was reached to $123{ }^{\circ} \mathrm{C}$ while in the non-modified reached to $113{ }^{\circ} \mathrm{C}$ on June 2017. The raise in absorber plate temperature inside the both cookers are increasing significantly when the both cookers are operated near to the solar noon. The absorber plate temperature of the modified was $8.13 \%$ more than the absorber plate temperature of the non-modified cooker when they reached to the maximum temperature.

There is no significant drop in temperature in both cookers after reaching the maximum temperature due to the thermal insulation.

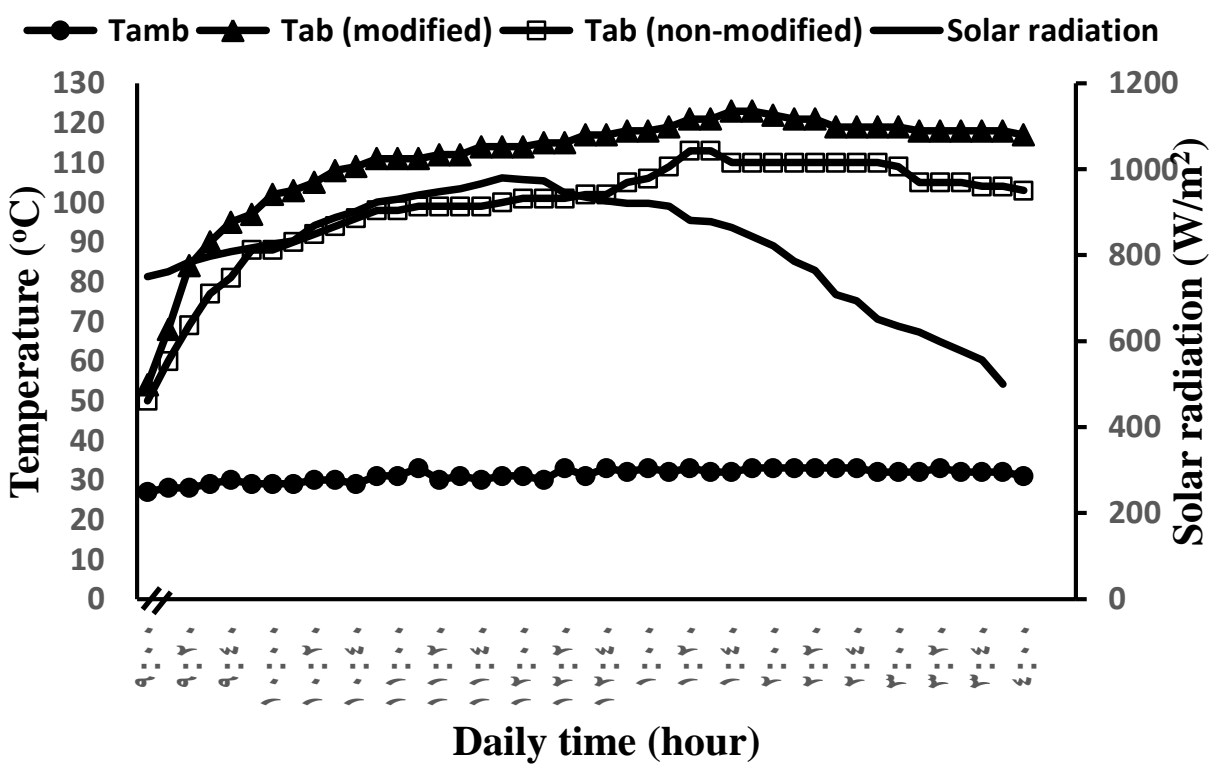

Fig. (4): Comparison between absorber plate temperature of modified and non-modified box solar cookers, solar radiation and ambient temperature (June 2017).

\section{Effect the type of cooker on the water heating}

The average maximum temperature of water heated by the modified cooker was 91,86 and $81^{\circ} \mathrm{C}$ with $0.5,1$ and 2 liter, as respectively as shown in Fig. (5) 


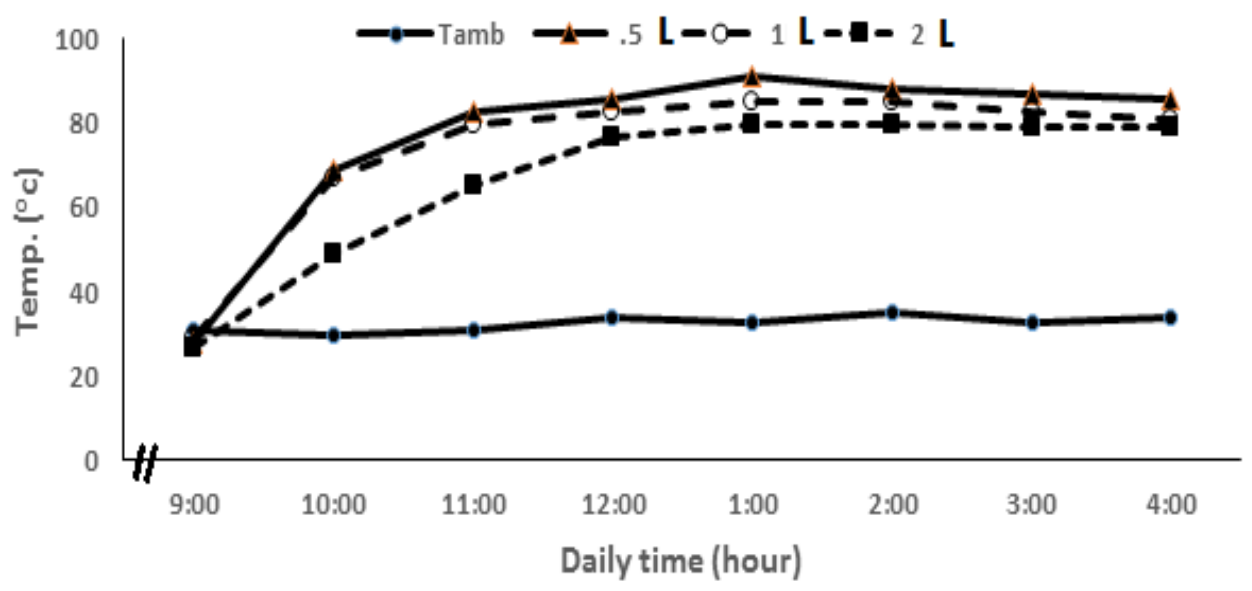

Fig. (5): Comparison between water temperature of modified box solar cookers of $0.5,1.0$ and 2.0 liter of water (June 2017).

\section{First figure of merit (F1)}

Under conditions $\mathrm{T}_{\mathrm{amb}}=34,35, \mathrm{~T}_{\mathrm{ab}}=123,110$ and solar radiation $=850$ $\mathrm{W} / \mathrm{m}^{2}$, the calculated values of $\mathrm{F} 1$ was 0.108 and $0.087{ }^{\circ} \mathrm{C} . \mathrm{m}^{2} / \mathrm{W}$ with modified and non-modified cooker types, respectively.

\section{Second figure of merit (F2)}

The second figure of merit F2 gives an indication of the heat exchange efficiency factor of the cooker. Consequently, the value of F2 was 0.262 and 0.089 for modified and non-modified cooker, respectively. Which also established the fact about the better cooking performance of the modified cooker.

\section{Energy efficiency of the solar cooker}

The mean energy gained of the modified box cooker for $0.5,1$ and $2 l$ of water was $135.8,250.8$ and $459.8 \mathrm{~kJ}$, respectively. While it was 102 , 200.6 and $351.1 \mathrm{~kJ}$ for $0.5,1$ and $2 l$ of water of the non-modified cooker, respectively. So, the added energy by the oil was 33.8, 50.2 and $108.7 \mathrm{~kJ}$ for $0.5,1$ and $2 l$, respectively.

The comparative results of energy efficiency of the cookers for $0.5,1$ and $2 l$ of water are shown in Figs. (6, 7 and 8). The obtained results clearly shown that energy efficiency is high initially and then decrease over times because the energy is being directly proportional to the temperature difference of the water. When the efficiency equal zero indicates that the temperature is held constant. The negative efficiency indicates that the 
cooker is losing heat. From the results, it was clearly seen that energy efficiency of the solar cooker with $2 l$ of water was higher than that with $0.5 l$ and $1 \mathrm{l}$. This is due to the fact that output energy is directly proportional to the volume of the water. The mean energy efficiency of the modified box cooker for $0.5,1$ and $2 l$ of water was 4.0, 6.6 and 12.1 $\%$, respectively. While, the mean energy efficiency of the non-modified box cooker for $0.5,1$ and $2 l$ of water was 3.3, 5.1 and $9.3 \%$, respectively.

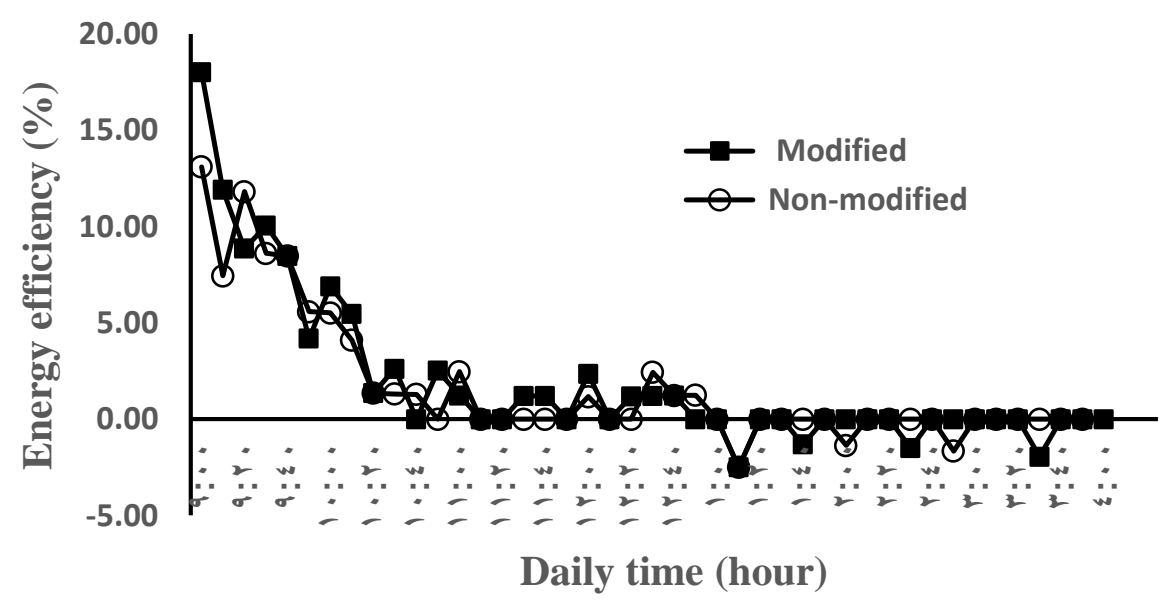

Fig. (6): Time versus energy efficiency for 0.5 litre of water in box solar cooker.

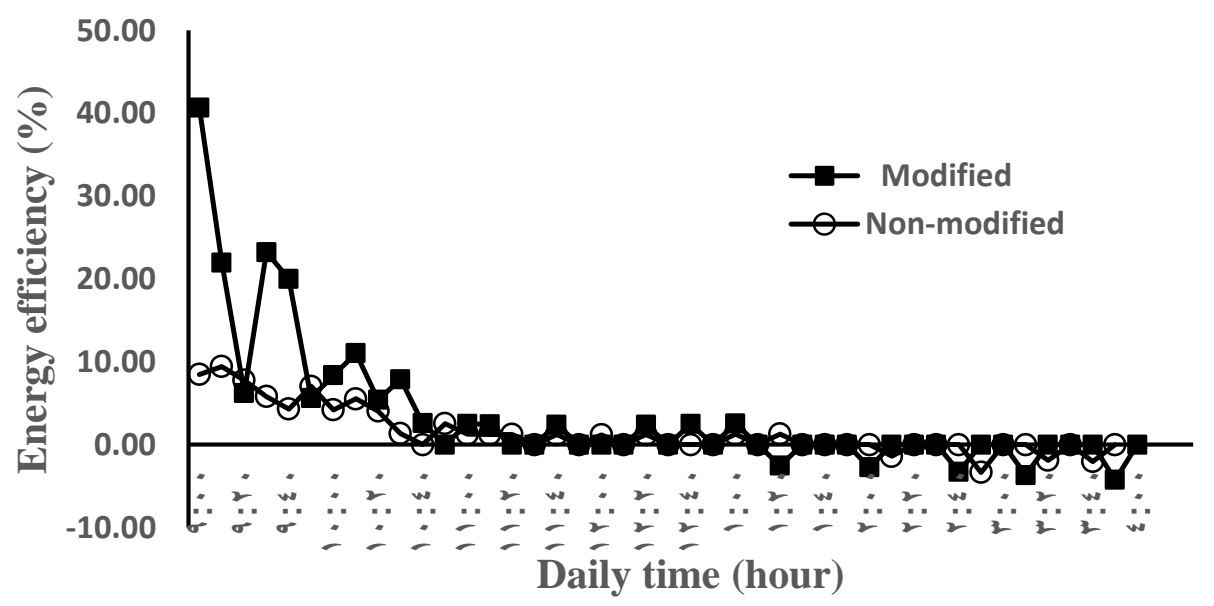

Fig. (7): Time versus energy efficiency for $1 \mathrm{~L}$ of water in box solar cooker. 


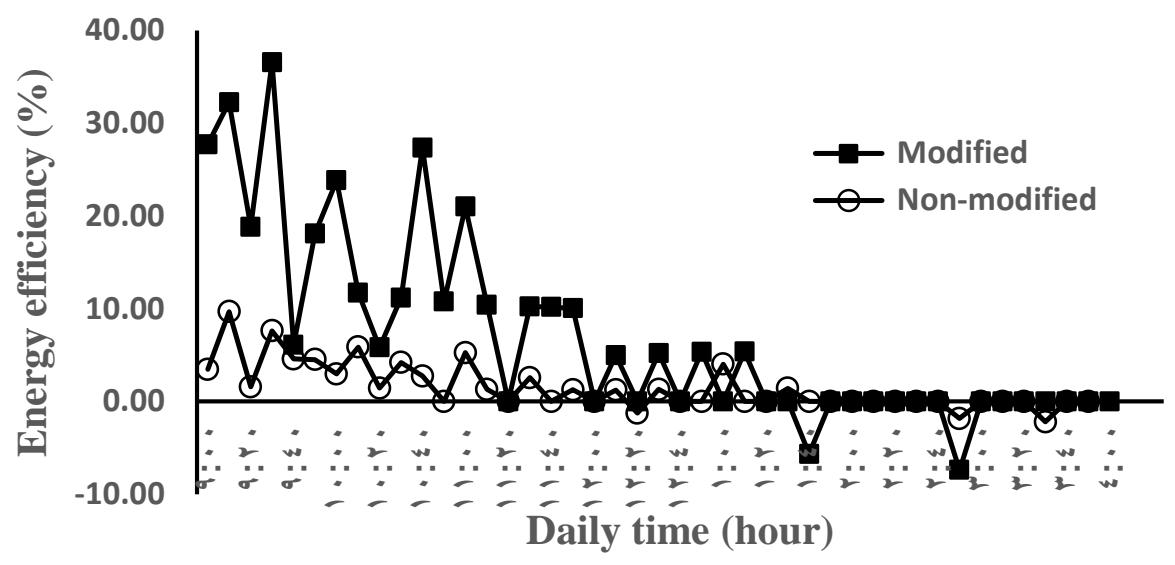

Fig. (8): Time versus energy efficiency for $2 \mathrm{~L}$ of water in box solar cooker.

Generally, the modified cooker achieved a higher thermal efficiency than the non- modified cooker by about $23 \%$ at the maximum water volume of 21.

\section{Productivity of the solar cooker}

The cooking was not achieved in the non-modified solar cooker. Fig. (9) shows that the quantities of cooked rice and the time required for cooking by the modified solar cooker. The total required time was reached about $110 \mathrm{~min}$ for cooking a $200 \mathrm{~g}$, while for a $1000 \mathrm{~g}$ of rice it was about 255 $\min$.

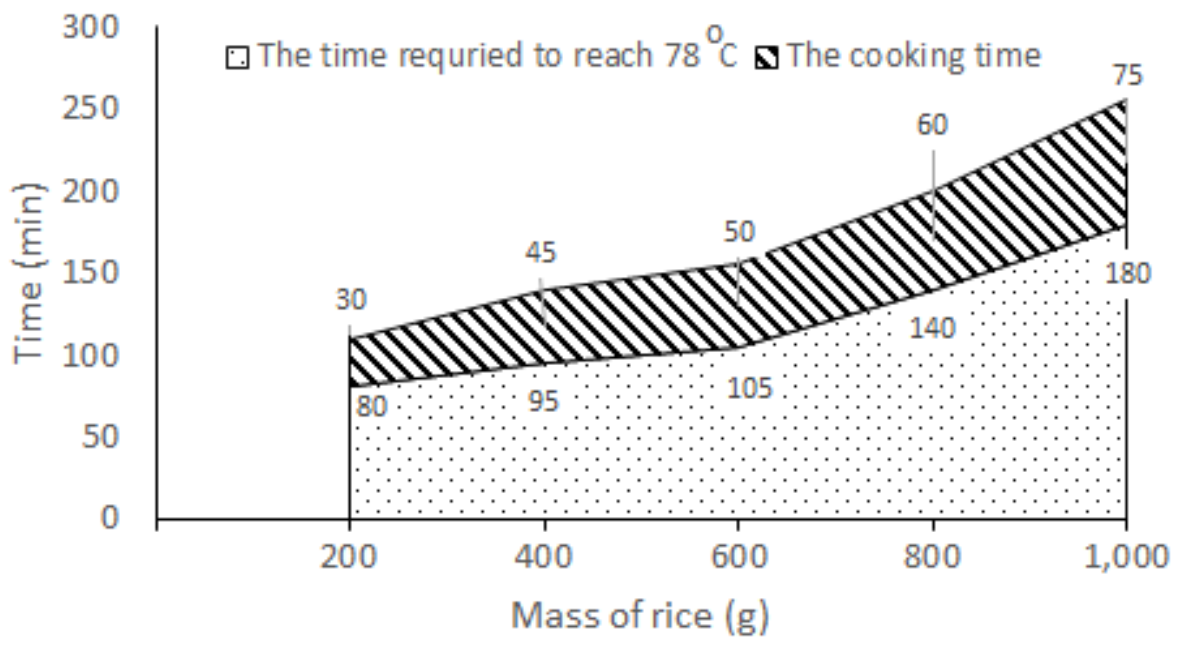

Fig. (9): The time required for cooking different quantities of rice by modified cooker. 
PROCESS ENGINEERING

\section{Baking biscuit}

Biscuit was baked at $115^{\circ} \mathrm{C}$ during 90 min for modified box solar cooker.

\section{Maturity of cooking}

The hardness of cooked rice ranged from 0.25 to $0.33 \mathrm{~N}$. The results of hardness was agreed with Syafutri et al., (2016), which indicates that the rice has cooked.

The hardness of biscuit ranged from 0.08 to $0.16 \mathrm{~N}$. The results of hardness was agreed with Burseg et al., (2009), which indicates that the biscuit has baked.

\section{Cost estimation}

The comparison between the cost of cooking by the modified solar cooker and the operational cost of the traditional gas cooker is shows in Fig. (10). The costs were 0.3 and $0.379 \mathrm{LE} / \mathrm{kg}$ for solar cooker and gas cooker, as respectively.

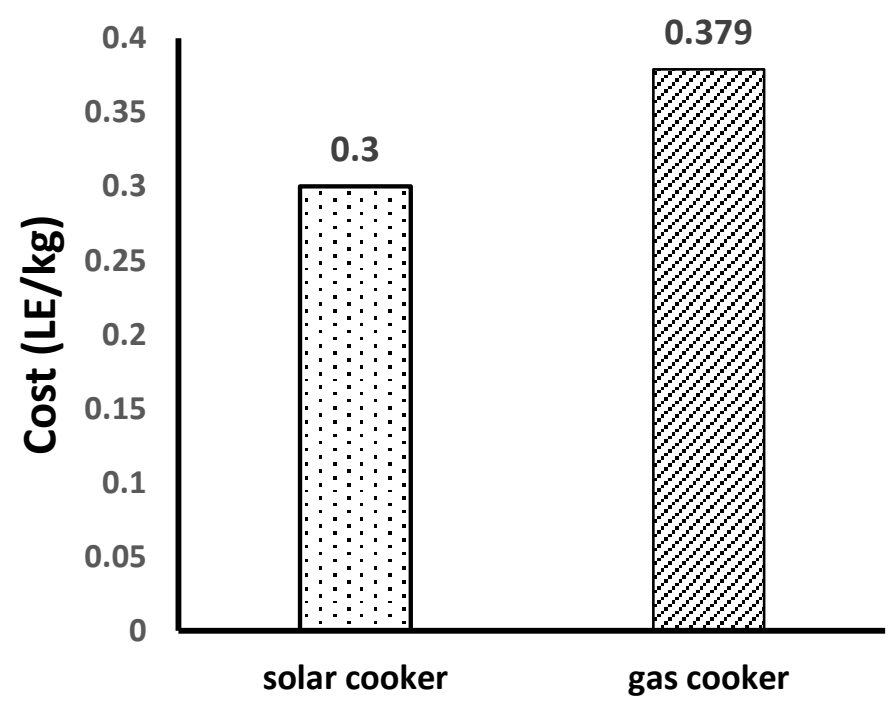

Fig. (10): Comparison between the cost of solar cooking and cooking by gas cooker $(\mathrm{LE} / \mathrm{kg})$.

\section{CONCLUSION}

A solar box cooker was built and was modified to improve its thermal performance. The thermal performance was evaluated by using first figure of merit, second figure of merit and energy efficiency. The concluded results from this study were: 
1- The absorber plate temperature of the modified box cooker was $8.13 \%$ more superior to absorber plate temperature of the nonmodified cooker when they reached to the maximum temperature.

2- The calculated values of F1 and F2 were indicated that the modified cooker is efficient.

3- The modified cooker achieved a higher thermal efficiency than the non- modified cooker by about $23 \%$ at the maximum water volume of $2 l$.

4- The perfect time to cook by using the solar cookers was from 11:00 AM to 3:00 PM.

5- The cost comparison indicates that using modified box cooker is economically.

6- The modified solar cooker saves about $20.8 \%$ of the operation cost of the traditional gas cooker.

\section{REFERENCES}

Amer, E.H., 2003, Theoretical and experimental assessment of a double exposure solar cooker. Energy Convers Manage. 44:2651-63.

Arenas J., 2007, Design, development and testing of a portable parabolic solar kitchen. Renew Energy; 32:257-66.

Ashok, k. and Sudhir, C.V., 2009, Proposal for new world standard for testing solar cookers, Journal of engineering science and technology, 4 (3): $272-281$.

Atia, M. F. M., Mostafa M. M., El-Nono M. A. and Abdel-Salam M. F. M., 2016, Milk Pasteurization Using Solar Concentrator with Tracking Device. Misr J. Ag. En. 33(3): 915-932.

Burseg, K., Robert S. T. L., Joanne H. and Andrew J. T., 2009, Flavor Perception in Biscuits; Correlating Sensory Properties with Composition, Aroma Release, and Texture. Chem. Percept, (2): 70-78.

Deliani, L., 2004, Studying the Effect of Several Rice Varieties Storage with Different Levels of Sticky on Parboiling Quality. Bogor, 
Indonesia: Faculty of Agricultural Technology, Bogor Agricultural University.

Duffle, J. A. and Backman W. A., 2006, Solar engineering of thermal processes. 3rd ed. New York: Wiley publications.

El-shal, H. M. S., 2016, thermal performance of an experimental car-tire solar cooker. Misr J. Ag. Eng., 33(1): 63-74.

Harmim, A., Belhamel M., Boukar M. and Amar M., 2010, Experimental investigation of a box-type solar cooker with a finned absorber plate. Energy. 35:3799-802.

Harmim, A., Merzouk M., Boukar M. and Amar M., 2012, performance sudy of a box type solar cooker employing an asymmetric compound parabolic concentrator. Eergy, 47:471480 .

Kumar, S., 2005, Estimation of design parameters for thermal performance evaluation of box-type solar cooker. Renew. Energy, 30: $1117-1126$.

Lee, L., Eun-Ji C., Dong-Kwang K., Chang-Hee K., Jun-Seok K., Young-Boong K., Eun-Mi K., and Jong-Dae P., 2015, Effects of Cooking Method on Physical Properties, Color, and Microstructural Characteristics of Scorched Rice Chips. Food Sci. Bio-technol., 24(5): 1673-1677.

Merzouk M., Harmim, A., Boukar M. and Amar M., 2012, Performance study of a box type solar cooker employing an asymmetric compound parabolic concentrator. Exergy, 47:471480 .

Mirdha, U. S. and Dhariwal S. R., 2008, Design optimization of solar cooker. Renew Energy. 33:530-44.

Negi B. and Purohit I., 2005, Experimental investigation of a box type solar cooker employing a non-tracking concentrator. Energy Convers Manage; 46:577-604 
Ozturk H., 2007, Comparison of energy and exergy efficiency for solar box and parabolic cookers. J Energy Eng;133(1):53-62

Saxena, A., Varun Pandey S. P., Srivastav G., 2011, A thermodynamic review on solar box type cookers. Renew Sustain Energy Rev. 15:3301-18.

Sonage, B. K. and Gavali S., 2015, Analysis of parabolic concentrator type solar cooker by using heat storing materials, Dissertation report.

Sorensen, B., 2003, Renewable Energy Its Physics, engineering, ues, environmental impacts, economy and planning aspects, $3^{\text {rd }}$ El sevier Academic press, Roskilde Uni., Energy \& Environment Group, Ins. 2, Denmark.

Syafutri, M. I., Filli P., Friska S., and Achmad F., 2016, Effects of Varieties and Cooking Methods on Physical and Chemical Characteristics of Cooked Rice. Rice Science, 23(5): 282-286.

Yusufzei, Z. K., 1994, Design and development of a solar collector. the second international seminar on Farm Machinery for developing countries, Tsukuba, Japan,Oct.12-13. pp. 101-121.

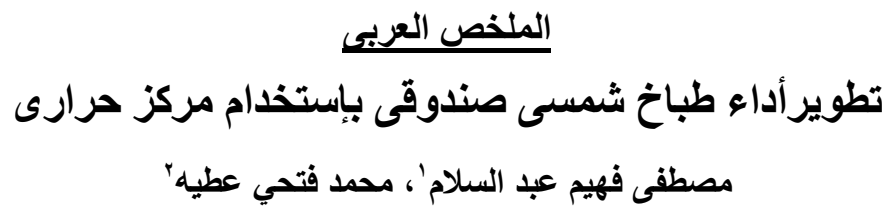

يعتمد السكان فى المناطق النائية وخاصة فى الدول النامية اعتمادا كليا على مصادر الطاقة

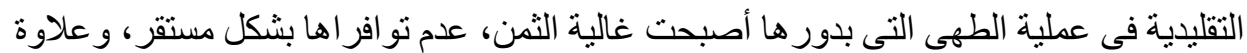
على أنها غير صديقة للبيئة. لذا تهدف هذة الدر اسة إلى تحليل وتقييم معدل الأداء لنموذجى طباخ شمسى صندوقى الثكل قبل

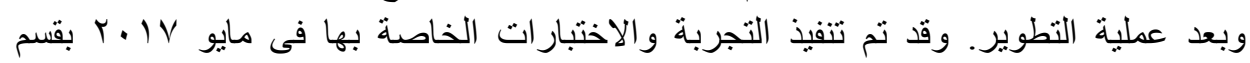

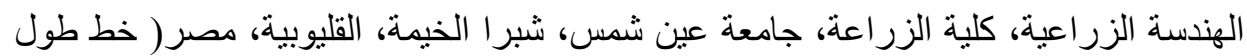

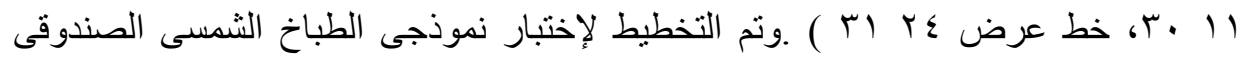

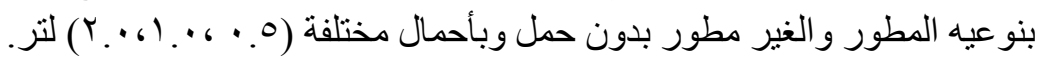

1 - أستاذ مساعد بقسم الهندسة الزراعية ـ كلية الزراعة - جامعةعين شمس. r ـ مدرس بقسم الهندسة الزراعية ـ كلية الزراعة - جامعةعين شمس. 


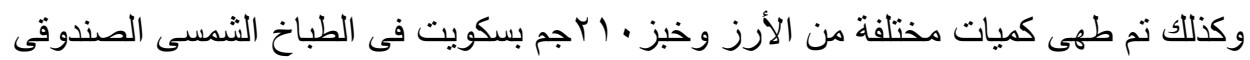

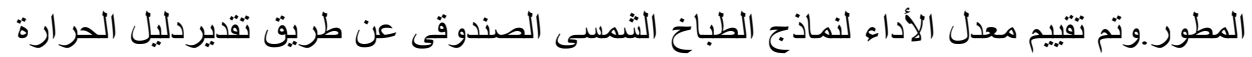

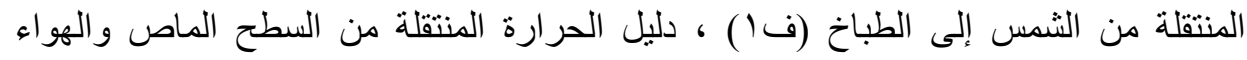

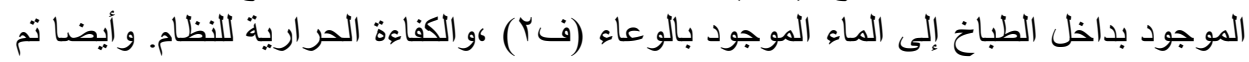
تقدير الصلابة للأرز و البسكويت بعد التسوية.

وتوصلت الدراسة إلى النتائج الأتية: -

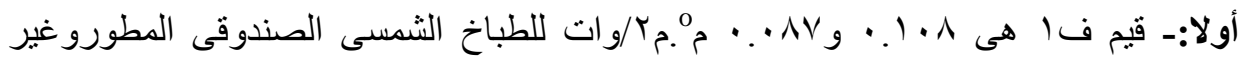

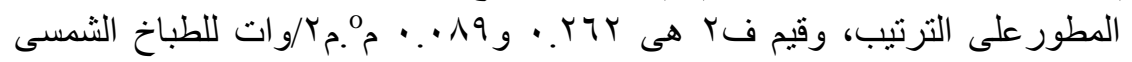
الصندوقى المطوروغير المطور على الترتيب.

ثانيا:- حقق الطباخ الثمسى الصندوقى المطور كفاءة حرارية أعلى من الغيرمطور بنسبة حو الي بr \% عند استخدام كمية مياه ب لتر.

ثالثا:- الطباخ الثمسى المطور وفر حو الى ^. • ب٪ من التكلفة التشغيلية للطهى التقليدى بالغاز.

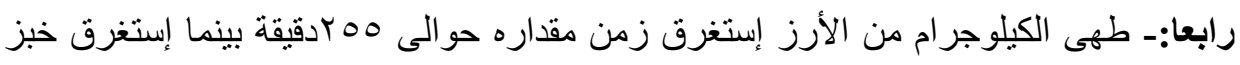

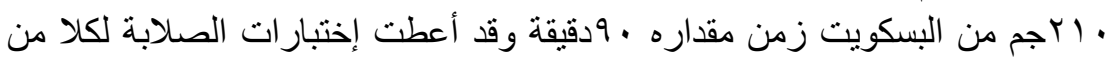
الأرز المطهى و البسكويت المخبوز نتائج مقبولة تنتو افق مع القيم المرجعية. 